\title{
Petroleum in the Philippines
}

\author{
By Warren DoPrf Smrta,* Ph. D., Edgene, Ore.
}

(New York Meeting, Februвry, 1920)

IT Has been 5 years since the writer left the Philippine Islands and while in that country his chief work did not lie in this field, though he has visited all but one of the localities mentioned in this article. The principal field studies relating to oil were $\mathrm{m}$, de by his colleague, Mr. Wallace E. Pratt. The writer's investigations, zalt with the general stratigraphy and paleontology of the Philippines. With the exception of the investigations made by Mr. Pratt and the writer very little information on this subject is available.

A number of geologists in the employ of large oil companies have visited the Islands from time to time but, following the general rule, the public has scarcely ever been permitted to learn anything of the results. The writer is indebted to the Bureau of Insular Affairs, Washington, for late information regarding recent legislation in the Islands relating to petroleum.

All the known oil seeps, petroleum residues, such as ozocerite, and natural-gas emanations are associated with Tertiary sediments. The chief seeps and most promising prospects are located as follows:

1. Bondoc Peninsula (lower end), Tayabas Province, Southeast Luzon.

2. The west coast of the island of Cebu from Alegria north to, and perhaps beyond, Toledo.

3. Central Mindanao not far from Lake Lanao.

4. The ozocerite veins on the Island of Leyte in the northwestern part in the vicinity of the town of Villaba.

5. Natural gas from some deep wells in Tertiary shale formations on the eastern flank of the Cordillera and extending out under the plain on the island of Panay.

The first mention in geological literature, to the writer's knowledge, of gas or petroleum in the Philippines is found in the description of the Island of Panay by the Spanish geologist, Abella, in the year 1890. In 1898, an oil well was being dug on the estate of Smith Bell \& Co., an English concern, near the town of Toledo on the west coast of Cebu. In

* Formerly Chief, Division of Mines, Bureau of Science, Manila. 
TABLE 1.-Provisional Table of Philippine Stratigraphy

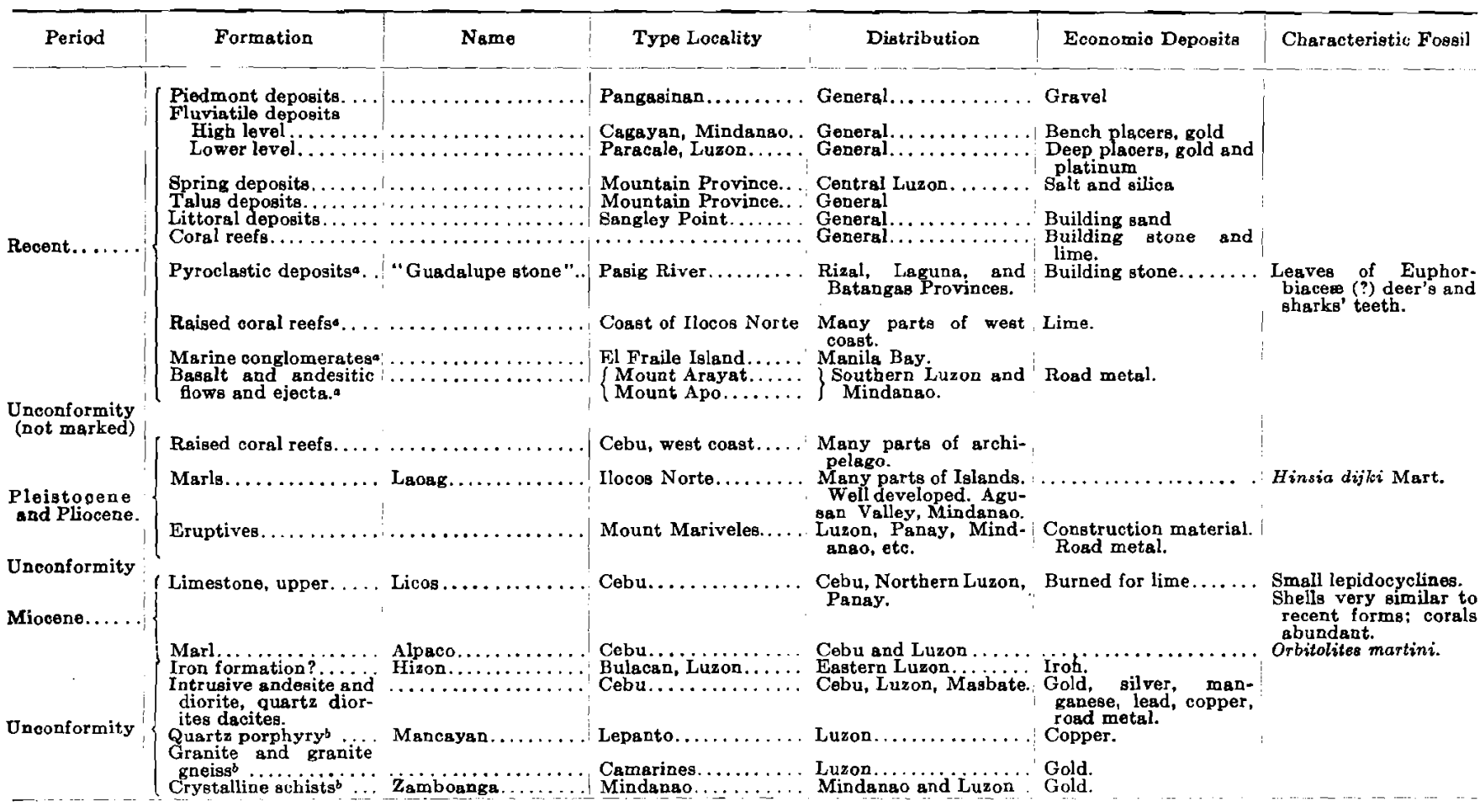




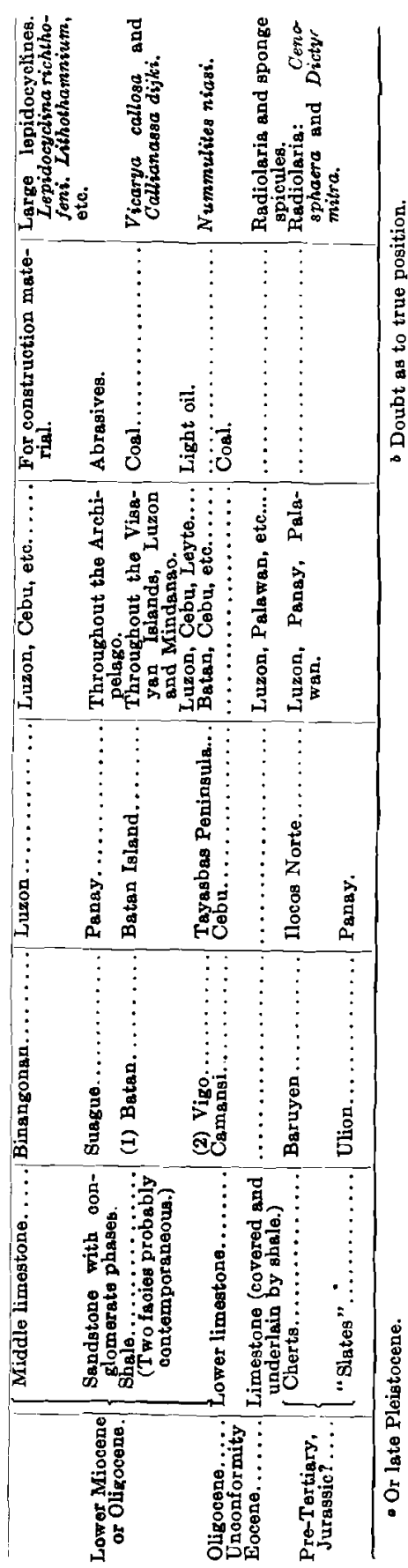

this year, an insurrection broke out against Spanish rule and the drillers were driven from the well, which was abandoned. It is now practically as the insurrectos left it; that is, choked with rubbish which would have to be cleared before operations could be renewed.

About 1910, a number of Americans became interested in the petroleum deposits known to occur on the peninsula of Tayabas in the southeastern part of Luzon, and which were apparently unknown to the Spaniards. Two wells 117 and $300 \mathrm{ft}$. (35 and $91 \mathrm{~m}$.) respectively, were dug from which a few gallons of oil were pumped, but nothing has been done since then, as far as we know. At the end of 1917, there was considerable excitement in the Islands over the alleged discoveries of oil in the Lanao region of the Island of Mindanao. The existence of petroleum on that island was known to the writer as early as 1908 , but he could not visit the localities owing to the hostility of the natives.

In 1919, an Act was passed by both branches of the Philippine Legislature, and approved by the Governor-General on Mar. 4, providing for the creation of the National Petroleum Co. This Act is as follows:

Section 1.-A company is hereby organized, which shall be known as the National Petroleum Company, the principal office of which shall be in the city of Manila, and which shall exist for a period of fifty years, from and after the date of the approval of this Act.

Section 2.-The said corporation shall be subject to the provisions of the Corporation Law in so far as they are not inconsistent with the provisions of this Act, and shall bave the general powers mentioned in said Law and such other powers as may be necessary to enable it to drill wells for the development of petroleum deposits, and to work said deposits and sell the output thereof. 
Section 3.-The capital of said corporation shall be five hundred thousand pesos, divided into five thousand shares of stock having a par value of one hundred pesos each, and no stock shall be issued at less than par nor except for cash.

Section 4.-The Governor-General, on behalf of the Government of the Philippine Islands, shall subscribe for not less than fifty-one per cent. of said capital stock, and the remainder may be offered to the provincial and municipal governments or to the public at a price not below par which the board of directors shall from time to time determine. Ten per centum of the value of all stock subscribed shall be paid at the time of the subscription, and the balance thereof shall be paid at such time as shall be prescribed by the board of directors. The voting power of all such stock owned by the Government of the Philippine Islands shall be vested exclusively in a committee consisting of the Governor-General and the presiding officers of both Houses of the Legislature.

Table 1 gives the provisional stratigraphic column of the Philippines. Table 2 furnishes a tentative correlation of the Far Eastern Tertiary stratigraphy including that of the Philippines. Some of the shales referred here to the Miocene may belong to the Oligocene. The oil horizon (there may be more than one) is probably in the Oligocene or the lower Miocene shales.

Attention is called to an error in the stratigraphic column given by the writer in one table in an earlier paper and incorporated by Pratt in one of his. ${ }^{1}$ In that table, the Oligocene is given as resting directly upon a pre-Tertiary complex. The Eocene is well developed in the Philippine coal fields and is doubtless to be found in the oil fields as well as in the coal fields, though perhaps not so extensively.

In view of a prevailing opinion that these islands are largely volcanic, it should be pointed out that there are large areas where the only surface rocks are sediments and other areas where volcanic rocks form a veneer over the underlying Tertiary sandstones, shales, and limestones. Intrusive diorite is found near the center of many of the large land masses and more rarely intrusive granite, andesitic and diabasic intrusive are also found in many places near the borders of the masses.

The section made by the streams flowing eastward from the cordillera of the island of Panay affords, perhaps, as clear a view of the sequence of strata comprising a part of the Tertiary as can be obtained anywhere in the Philippines. The dominant formation is shale with thin-bedded, intercalated sandstones of which there are some $15,000 \mathrm{ft} .(4572 \mathrm{~m}$.) along the Tigum river. These shales belong torthe same horizon as those in the Bondoc Peninsula, known as the Vigo series, and are Lower Miocene or Oligocene. This shale yields small amounts of natural gas, which may or may not have any relation to small coal seams.

Apparently there are three principal shale horizons; lowermost, the Eocene, which is associated with sandstones and coal seams; next, the Oligocene or Lower Miocene, in which the oil seeps are found; and uppermost, the Miocene with more coal seams.

1 Occurrence of Petroleum in the Philippines. Econ. Geol. (1918) 11, 247. 
TABLE 2.-Tentative Correlation of the Far Eastern Tertiary

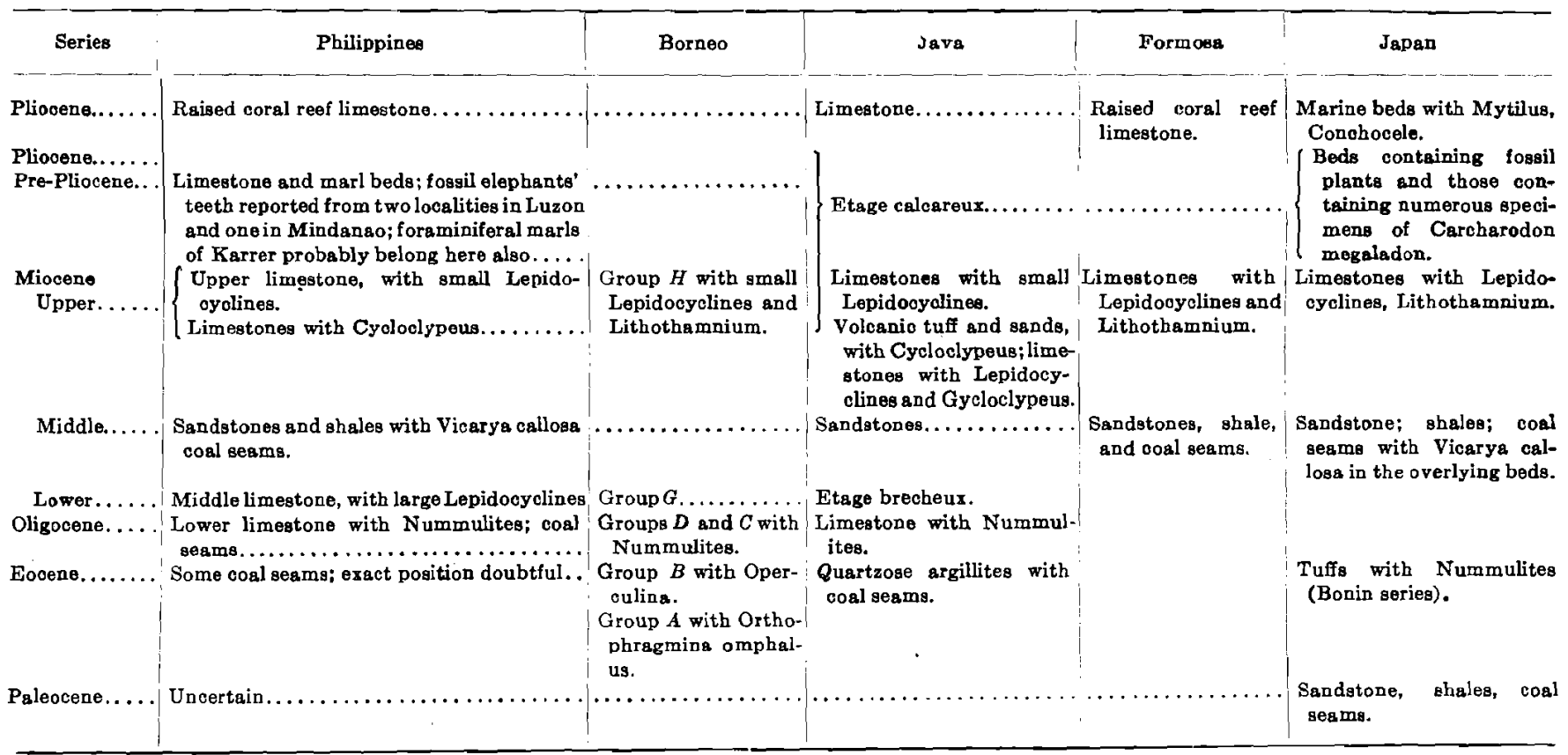


The typical oil (Vigo) shale on Bondoc Peninsula may be described as (quoting from report of Pratt and Smith, p. 331) "consisting of finegrained shale and sandy shale interstratified in thin regular beds from 5 to $10 \mathrm{~cm}$. in thickness. Occasional beds of sandstone occur varying from $10 \mathrm{~cm}$. to $1 \mathrm{~m}$. in thickness. The fine-grained shale is gray, blue, or black and is made up almost entirely of clay. The blue or black finegrained shale in the Vigo formation usually emits a slight odor of light oils upon fresh fracture and in some outcrops is highly petroliferous. The material loses this odor and assumes a light-gray color after it has been exposed to the air and becomes thoroughly dry." These shales contain numerous foraminifera of the genus Globigerina, which may be the source of the oil. Although present numerously, these organisms did not appear to comprise any large percentage of the volume of these shales.

On the island of Cebu there is a similar shale series, dark blue in color and fine-grained, in which the oil seeps are found.

Another important feature of the Philippine Tertiary is the presence of several limestone horizons in striking contrast to the American west coast Tertiary. These limestones, in places, attain thicknesses of several hundred feet.

In general, we may say that the Philippine Islands consist of a series of anticlinal regions, which are marked by the island masses, and synclines, which are occupied by the narrow straits between the islands. The principal folding has been east and west, with minor flexures north and south. The anticlines are generally sharp, as is the case in Sumatra, Java, Burma, and other parts of the Far East. In South Sumatra, Tobler has shown that the anticlines are only $2000 \mathrm{ft}$. across the crest and that wells must be located on the crest in every case. In Tayabas, the structure can easily be understood by a study of the map accompanying the paper by Pratt and the writer. This shows that the anticlines are generally sharp and the dips are quite steep. The Maglihi anticline on Bondoc Peninsula is a typical example and less than $1 / 2$ mi. wide. The axis of the principal structures coincides with the general direction of the principal tectonic lines of the archipelago; i.e., north and south with minor departures from this. Accompanying this folding there has been more or less faulting. Just how great the throws are, not enough detailed work has been done to determine. There is enough evidence to indicate a considerable amount of faulting throughout the archipelago.

On Cebu, Pratt has shown that the seeps near Alegria are located at the crest of a very sharp anticline. The well near Toledo, which shows some oil, is apparently on a monocline in which the beds dip $50^{\circ}$ to $60^{\circ}$ to the northwest.

In Leyte, the petroleum seeps are along the outcrops of steeply dipping strata (Vigo shale series). 
On Panay, the shale beds yielding natural gas are generally monoclinal, but there is one well-defined anticline, known as the Maasin anticline, which might be a favorable location for a test well.

In Tayabas and Cebu, there is a sandstone member, to which the local name "Canguinsa sandstone" has been given, which lies unconformably upon and overlapping the great shale series. In some cases, as in Leyte, residual bitumens are found in this formation.

Very probably, transportation will depend on inter-island boats as most of the $750 \mathrm{mi}$. of railroad in the archipelago does not tap the petroleumlocalities. In the transportation of machinery and the location of docks, great care will have to be exercised because of typhoons.

Labor is plentiful but unskilled. However, the Filipinos show a great aptitude along mechanical lines and, under competent white foremen, make very excellent workmen. The prices for labor vary with the different tribes and localities. Present prices are commensurate with those in other parts of the world. The Filipino's fondness for holidays ne-

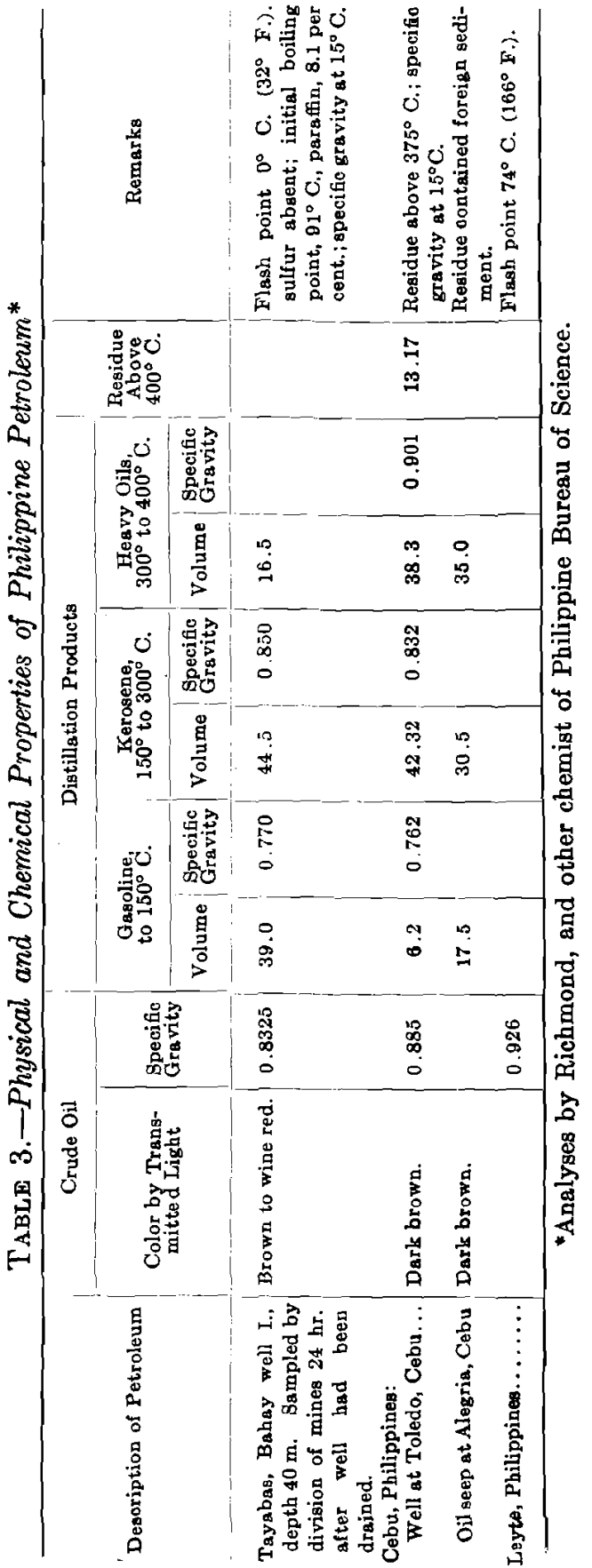


cessitates a larger pay-roll than is usually warranted by the size of the job. The manager will have to take this into account.

Philippine petroleum has a paraffine base and is usually reddish to violet in color. It is quite clear, and closely resembles oil from Burma and Sumatra. Table 3 gives a fairly complete analysis made by Richmond, former chemist of the Bureau of Science, and others. Table 4 contains an analysis of the petroleum residue from the Island of Leyte. The paraffine content of the Philippine petroleum is very high; a beer bottle full of oil from the Toledo well in 1908, which the writer collected and put imperfectly sealed into his saddle bags, on unpacking three days later, contained no oil but was half full of solid paraffine.

The residual bitumens from Villaba, Leyte, are found in lenses and pockets in the Canquinsa sandstone. These have been fully investigated by Pratt. Physically they more nearly correspond to ozocerite than to any other of the natural bitumens.

Table 4.-Physical Properties of Natural Bitumens from Villaba, Leyte

\begin{tabular}{|c|c|}
\hline Property & $\begin{array}{l}\text { OUTCROP } \\
\text { A AND B }\end{array}$ \\
\hline Specific gravity... & 1.05 \\
\hline Hardness. . . . . . . & 2.00 \\
\hline Color..... & Jet black \\
\hline Streak........ & Black \\
\hline
\end{tabular}

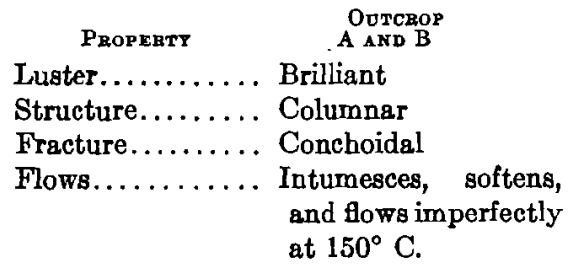

ODTCROP

Brilliant

Inturnesces, softens, at $150^{\circ} \mathrm{C}$.

The writer agrees with Pratt in the belief that there is a small commercial supply of oil in the Philippines, very much as in Formosa. He seriously doubts, however, that petroleum exists in large enough quantities to attract large capital from America, considering the distance and the many unfavorable conditions to be encountered. The size, steepness of dip, and broken nature of many of the structures are not favorable to large production.

All the oil which the writer has seen in the Islands is in the shallow wells mentioned and in seeps in shales, and these seeps have been small. Ho has seen no oil in beds either below or above these shales. In the petroliferous shales are a number of forminifera with Globigerina predominating. It may be that all the oil has come from the decomposition of these organisms.

\section{DISCUSSION}

Wallace E. Prate, * Houston, Tex. (written discussion).-Doctor Smith's correction of my statement in Economic Geology that the Philippine Oligocene rests directly upon a pre-Tertiary basement of crystalline

* Chief Geologist, Humble Oil \& Refining Co. 
rocks is well taken. I concede that some of the older indurated shales and limestones may properly be classed as Eocene. My statement should have been limited to the petroleum-bearing areas that I described and in which it applies by reason of the absence of the older rocks.

In this connection, I may record my impression that the typical Philippine section is not as thick as the $15,000-\mathrm{ft}$. (4572 m.) section exposed on the eastern flank of the cordillera of the Island of Panay and mentioned by Doctor Smith. I think the average thickness for the Philippine sedimentary column would be about one-third of the figure quoted. The Panay section is unusual in another respect; at its base there are thousands of feet of unfossiliferous conglomerates and coarse sands which appear to be of extreme shallow-water origin, whereas in the typical column this basal member is not more than $200 \mathrm{ft}$. $(61 \mathrm{~m}$.) thick.

A rocent press dispatch states that Cebu, the second largest port in the Philippine Islands, and a city of about 100,000 population, is now paving its streets with rock asphalt secured from a quarry in the vicinity of the town of Villaba, on the neighboring island of Leyte. I believe this work marks the first commercial use of the petroliferous deposits of the Philippines. The circumstance is interesting not only as a first step in making this natural resource serve industry, but as an evidence of the extent of the residual deposits that constitute the surface indications of petroleum in one of the possible oil fields in the Philippines.

As a matter of fact, not only is the stratigraphic column in the Philippines-dominantly shale with interbedded sandstone as described by Doctor Smith-of suitable character and adequate thickness to yield commercial petroleum, but the surface evidences of the existence of petroleum on some of the islands are quite remarkable. These various seepages and asphalt deposits are described briefly in my paper in Economic Geology to which Doctor Smith refers. ${ }^{2}$

The situation in the Philippines, in so far as the geologic conditions are concerned, is certainly one that would lead many of the geologists engaged in the present fervid search for new petroleum fields to recommend drilling exploration on some of the islands, provided their clients commanded adequate capital. The possibilities in the Philippines are the more impressive when one reflects that in Borneo, Sumatra, and Java, as well as in Formosa and Japan, commercial production of a petroleum similar in character to that which comes to the surface at places in the Philippines is obtained from beds of the same geologic age and composition as those in the Philippines.

${ }^{2}$ More detailed descriptions with maps and geologic sections will be found in the following references: Wallace E. Pratt and Warren D. Smith: Geology and Petroleum Resources of the Southern Part of Bondoc Peninsula, Tayabas Province, Philippines. Phil. Jnl. Sci., Bur. Sci., Manila (1913) Sec. A, 5, 301-376; Wallace E. Pratt; Occurrence of Petroleum in Cebu, Idsm. (1915) Sec. A, 4; Wallace E. Pratt: Petroleum and Residual Hydrocarbons in Leyte, Idem. (1915) Sec. A, 4. 
Under different conditions, a prospect like that in the Philippines would evoke an active drilling campaign. I have had opportunity to make direct comparison in the field between conditions in parts of Central America, for instance, and in the Philippines and I can conceive no possible contention but that the geologic conditions in the Philippines are decidedly the more promising. Yet these same regions in Central America have interested dozens of large petroleum corporations; concessions there have been sought eagerly for years and are at present, indeed, being exploited.

I am convinced that adequate exploration of the petroleum deposits in the Philippines has been prevented, not by unfavorable geologic conditions but by prohibitive regulations of the local mining laws. Practically all the possibly petroleum-bearing territury in the Philippines is government land. It can be acquired only under laws similar to the mining laws of the United States. Petroleum lands are subject to "location" as placer-mining claims. An individual may obtain a single claim of 8 hectares ( 20 acres) in any one field while a corporation comprising eight individuals can secure only one claim of 64 hectares (160 acres) in any one field. Except by a direct evasion of the law, therefore, it is impossible to control the acreage requisite for large operation, such as must be contemplated by any enterprise that looks as far afield as the Philippine Islands.

It is unlikely that successful exploration will result from the efforts of the Government owned corporation, the formation of which is recorded in the legislation quoted by Doctor Smith. This corporation, like any other, is subject to the laws that prevent the acquisition of suitably large holdings and its capitalization of 500,000 pesos $(\$ 250,000)$ is not adequate. If the Filipinos were to grant concessions of hundreds of thousands of acres, as some of the Central and South American republics have done, I believe their possible petroleum resources would be promptly and thoroughly tested by the drill.

David WhITE, ${ }^{*}$ Washington, D. C.- This paper is very timely since the Philippine Islands are presumably open to the enterprise of the American driller, whereas much of the territory in that part of the world is closed to us.

The United States has ambitious plans for the operation of a great merchant marine, which is to be oil burning in the main, and it takes but a glance at the world map to see the strategic advantage of oil supplies in the Philippines for such marine operations. It is a little difficult to understand why more attention has not been given to the Philippines, in spite of the difficulties attending development in these islands.

* Chief Geologist, U. S. Geol. Survey. 
A number of American oil companies are, I believe, at the present moment taking an interest in the possibilities of the Philippines. Important factors in the formulation of opinion regarding the importance of the oil deposits of the Philippines, as brought out by Mr. Pratt, are the point of view and the breadth of experience of the examining geologist. The average oil geologist, whose experience has been mainly in the Appalachian region, the Mid-Continent, or Louisiana, or possibly even in California, on seeing the narrowness of the basins, the closeness of the folding, and the presence of igneous rocks here and there, would be likely to draw unfavorable conclusions as to the possibilities of the Philippine Islands. Geologists visiting that region should be familiar with the geological conditions of oil occurrence in Japan, Formosa, the East Indies, or in the Baku district, and their conclusions should be formulated with the knowledge and understanding of the occurrence of oil in those regions rather than in the United States. 